\title{
Petrophysical parameters estimation and reservoir characterisation based on well log data in the Joya Mair Oil Field, Minwal X-01 Well, Potwar Sub-Basin and Upper Indus Basin of Pakistan
}

\author{
Mubashir Mehmood ${ }^{1^{*}}$, Muhammad Yaseen ${ }^{2}$, Ikram-ud-din ${ }^{3}$, Muhammad Jehangir Khan ${ }^{1}$, \\ Tanveer Ullah ${ }^{3}$ and Anwarulhaq ${ }^{3}$
}

\author{
${ }^{1}$ Institute of Geology, University of the Punjab Lahore, Pakistan. \\ 2Department of Geology, Abdul Wali Khan University Mardan, Pakistan. \\ ${ }^{3}$ Department of Geology, Shaheed Benazir Bhutto University Sheringal Dir Upper, Pakistan.
}

${ }^{*}$ Corresponding author. Email: mubashirmehmood94@gmail.com

Copyright (C) 2018 Mehmood et al. This article remains permanently open access under the terms of the Creative Commons Attribution License 4.0, which permits unrestricted use, distribution, and reproduction in any medium, provided the original work is properly cited.

Received 2nd August, 2018; Accepted 11th October, 2018

\begin{abstract}
The aim of this study is to assess the reservoir potential of the Eocene age Chorgali and Sakesar formations encountered in Minwal X-01 Well Potwar Sub-Basin. The current study is concerned with the reservoir potential evaluation using petrophysical approach of Minwal X-01 located in Potwar basin. Minwal X-01 is selected for research, where the prevailing assessment involves identifying, marking, analysing and interpreting the reservoir zones from well logs and computational analysis through different formulas. Several well logs were used comprising sonic log, gamma ray log, density log, neutron log, and resistivity logs. The petrophysical parameters such as the shale volume (Vsh), total porosity (PHT), effective porosity (PHE), water saturation (Sw), hydrocarbon saturation (Sh), and pay zone were assessed from wireline logs. The best possible reservoirs in the study area are Chorgali and Sakesar formations in Minwal X-01. These reservoirs have good net pay zones thicknesses (20-52 feet). Based on well log data, these reservoirs are classified as excellent reservoirs owing to their high effective porosity and hydrocarbon saturation.
\end{abstract}

Key words: Evaluation, Minwal, Pay zone, petrophysical analysis, Potwar basin, porosity, saturation, reservoir.

\section{INTRODUCTION}

The detail stratigraphy of the Joya Mair area was studied by Fatmi (1973). Shami and Baig (2002) worked out the structure of the Joya Mair oil field on the basis of aerial photographs and marked it as a triangular zone. Subsurface structural analysis of Joya Mair oil field was carried out by Zahid et al. (2014), using 2D seismic and well logs data suggesting the presence of a triangular zones in the subsurface and marked Sakesar Limestone as a primary reservoir at the depth of $\sim 2023 \mathrm{~m}$ in the Minwal X-01.

Petroleum resources are the backbone of a nation and its consumption and need are going to peak with time.
Petrophysics and well logging has a role of backbone in oil exploration sector. Well logging is a quick procedure and has a vital part in the oil industry as it brings cuttings of well as topographical examining to the surface and the process is not so much complex (Rider, 2002). The current approach is to explore the petrophysical parameters of Minwal X-01 well from Joya Mair Oil Field on the basis of well log analysis and the petrophysical parameters. The Joya Mair Oil Field lies in the south-eastern part of Salt Range Potwar foreland basin and is surrounded by Soan Syncline in the North and the Salt Range in the South (Figure 1). Chorgali and Sakesar formations are the main 


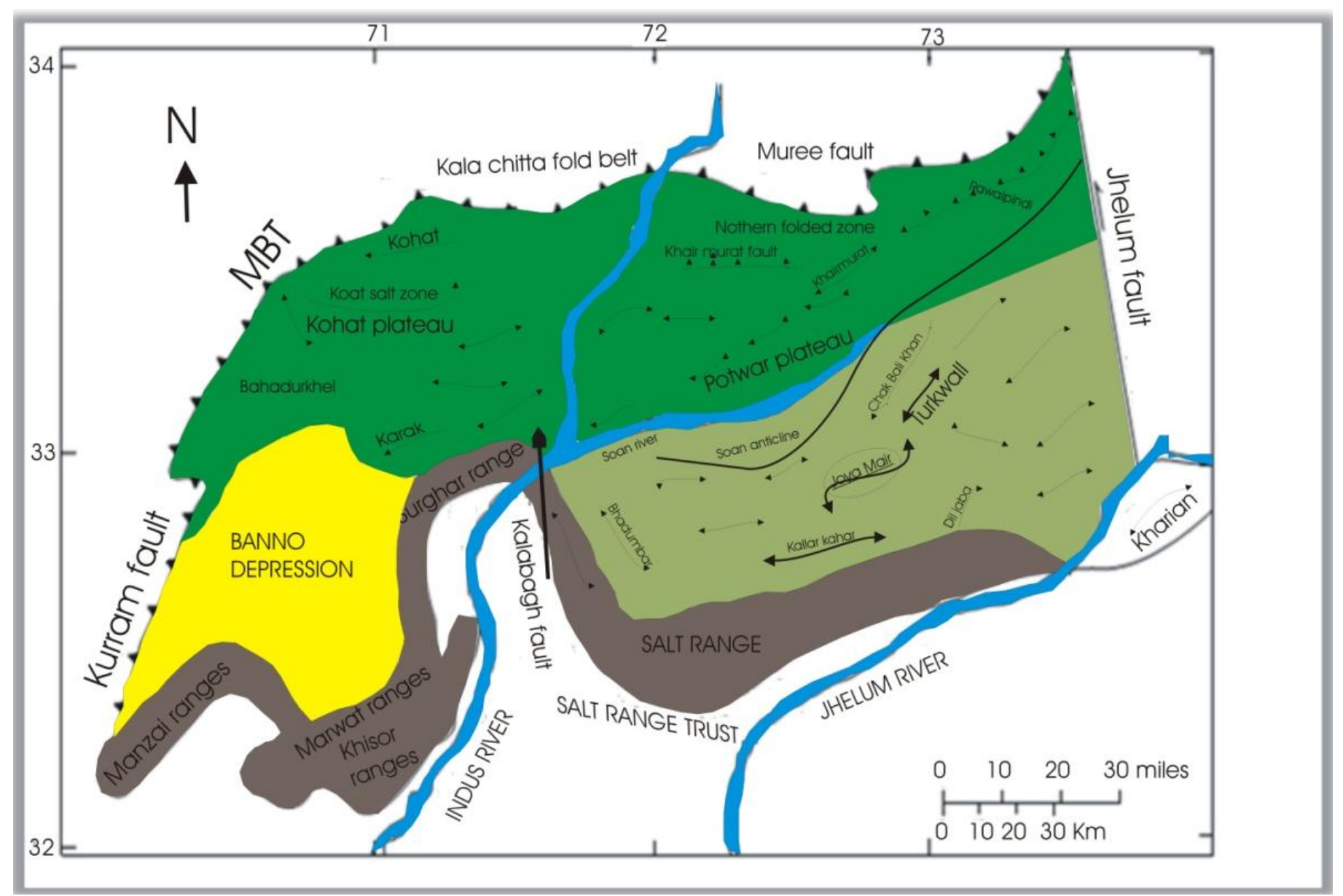

Figure 1. Showing structural map of the Kohat-Potwar Plateaus, northern Pakistan showing study area (Khan et al., 1986).

producing in Joya Mair area. The Salt Range Potwar foreland basin is regarded as one of the earliest parts of Pakistan investigated for hydrocarbons (Khan et al., 1986). In the northern Pakistan, Potwar and Kohat sub-basin are the home of Pakistan's oldest oil and gas producing fields like Dhulian 1936 and Joya Mair 1944 (Kadri, 1995). Upper Indus basin is an important hydrocarbon unit but has less published data is available regarding the Joya Mair oil field. Well logs of Minwal X-01 well were studied in detail in order to get detail information related to the assessment of petroleum reserves, rock properties and the reservoir and hydrocarbon potential of those formations, explored in the drilling of these wells.

The aim of the current work is to assess the reservoir potential of the rocks encountered in Joya Mair oil field. The objectives of this research includes identification and marking the potential hydrocarbon and water-bearing zones; determination of lithology; calculation of porosity $(\varphi)$, density porosity $(\varphi D)$, effective porosity $(\varphi \mathrm{e})$ and total porosity $(\varphi \mathrm{t})$; calculation of resistivity of water; identification of moveable hydrocarbon in zone of interest; and calculation of net pay in each reservoir interval.

\section{Geological setting}

The outgoing tectonic stresses has resulted in the formation of Indian, Eurasian and Arabian plates. The collision and interaction of these plates have led to the birth and generation of spectacular mountain belts including Himalayas, Karakorum and Hindukush. The rifting of Gondwana occurs in Permo-Triassic time (Searle, 1988). The continuous movement of Indian plate leads to the collision of Indian and Eurasian plate and ultimately Tethys Ocean closed. A series of thrust faults were developed due collision and thrust tectonic movements' i-e Main Karakoram Thrust (MKT), Main Mantle Thrust (MMT), and the Panjal Thrust in the north (MCT) (Gansser, 1981). Salt Range, Potwar and Kohat sub-basin marks the southern margin of Himalayan collision zone in Pakistan. In the eastern side the Salt Range and Potwar are bounded by left lateral, strike- slip Jhelum Fault. The western boundary of Potwar is not very sharp. The EW trending thrusts in the northern part of Potwar extend westwards to Shakardara area in Kohat Plateau while Kala Bagh Fault in the southern parts marks the western boundary of Potwar 


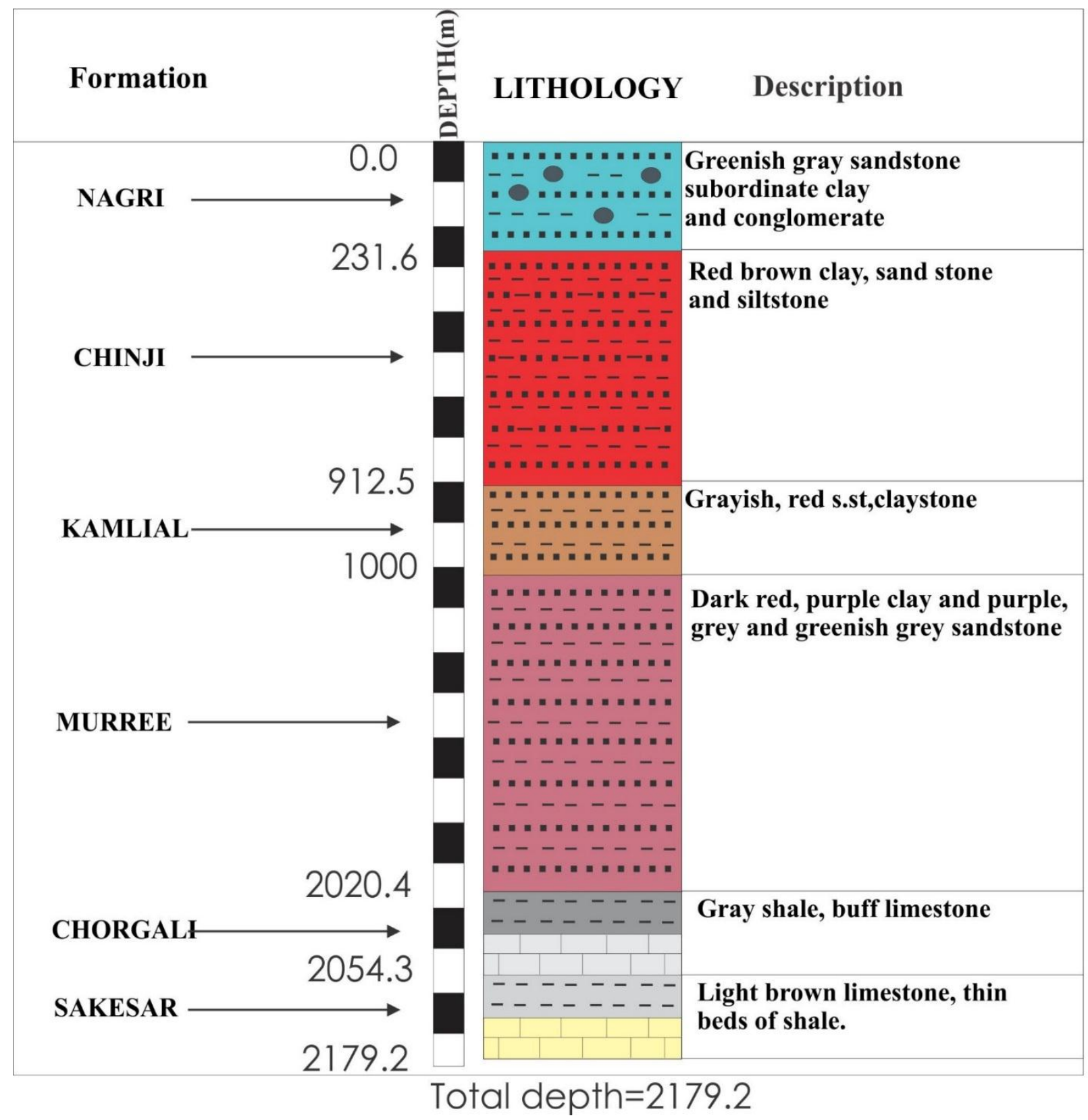

Figure 2. Showing Stratigraphy of Minwal X-01 (Zahid et al, 2014).

Plateau and cis-Indus Salt Range. The complex structural geometries in the Upper Indus Basin of Pakistan produced numerous petroleum prospects (Kadri, 1995). These structures ensued by compression tectonics at the foreland margin, basement uplift in the platform areas and extensional tectonics (Kadri, 1995).

\section{Generalized stratigraphy of studied well}

In Minwal X-01 rocks ranging from Palaeocene to Eocene rocks. The formations encountered are Nagri, Chinji,
Kamlial, Muree, Chorgali, Sakesar limestone. Chorgali formation and Sakesar limestone have been studied in detail from Minwal X-01, detail stratigraphy has been shown in Figure 2.

\section{METHODOLOGY}

Different petrophysical parameters have been find out using conventional logs including resistivity logs (LLD, LLS), Caliper, Spontaneous potential, Sonic $(\Delta t)$ and Gamma-ray (GR). Calculation of petrophysical properties 
Table 1. Showing formula's used for finding petrophysical parameters.

\begin{tabular}{|c|c|}
\hline Parameter & Formula \\
\hline Porosity & $\emptyset=\frac{V_{\text {pore }}}{V_{\text {bulk }}}$ (Darling, 2005 )15 \\
\hline $\begin{array}{l}\text { Effective Porosity } \\
\text { Absolute Porosity } \\
\text { Average Porosity }\end{array}$ & $\begin{array}{l}\mathrm{PHIE}=\mathrm{PHI}{ }^{*}(1-\text { Vshl })(\text { Schlumberger, 1967) } 16 \\
\Phi \mathrm{T}=(\phi D+\phi N) 2(\text { Rider, 1996) } 17 \\
\emptyset \mathrm{a}=(\varnothing \mathrm{d}+\emptyset \mathrm{n}) / 2(\text { Rider, 1996) } 18\end{array}$ \\
\hline Sonic Porosity & $\emptyset_{\text {sonic }}=\frac{\Delta_{\text {tlog }-\Delta_{\text {tma }}}}{\Delta_{\text {tf }-\Delta_{\text {tma }}}}($ Wyllie et al., 1958) 19 \\
\hline Permeability & $Q=\frac{K \Delta A}{\mu . L} \quad($ Selley, 2000) \\
\hline Water Saturation & $S w=\sqrt[n]{(a \cdot R w / \emptyset m \cdot R t)}($ Archie, 1942; Rider, 1996) \\
\hline $\begin{array}{l}\text { Hydrocarbon Saturation } \\
\text { Bulk volume of water }\end{array}$ & $\begin{array}{l}\text { Sh }=1-\text { Sw } \quad(\text { Rider, 1996) } \\
\text { BVW }=\text { Sw}^{*} \emptyset \mathrm{a}(\text { Rider, 1996) }\end{array}$ \\
\hline Volume of Shale & $\begin{array}{l}\text { IGR= (GRlog- GRmin)/(GRmax- GRmin) } \\
\text { (Asquith and Krygowski, 2004).21 }\end{array}$ \\
\hline
\end{tabular}

includes shale volume (Vsh), porosity $(\varphi)$, permeability $(k)$, density $(\rho)$, water saturation (Sw), hydrocarbon saturation (Sh) and bulk volume of water (Vb.w). Table 1 shows formulas used for finding petrophysical parameters/properties. All the logs were analysed by the computational method through various formulas of MS Excel 2013.

Value of the resistivity of water has been calculated through Schlumberger Gen charts and this value has been found out in three steps: (1) Rmf temperature has been plotted from well log on the graph (Figure 3); (2) value of Rmf equivalent with respect to $\mathrm{Sp}$ log has been plotted to find out the value of Rmf equivalent (Figure 4); and (3) the resultant value is finally plotted on the graph to find out the Rw value (Figure 5).

\section{Resistivity log response of Minwal X-01 for Rw calculation}

The response of resistivity log has been used to determine the saturation of water which was further used to determine the saturation of hydrocarbons. The average value of LLD in area of interest (AOI-1) was $174 \mathrm{ohm}-\mathrm{m}$, the average value of LLS in area of interest AOI-1 was 160 ohm-m.

\section{Resistivity of water $(\mathbf{R w})$}

The GEN charts were used to calculate Rw for this Minwal X-01 and its value was used to calculate other factors of the area of interest (AOI) selected for petrophysical investigations i.e. Saturation of water ( $\left.\mathrm{S}_{w}\right)$ and Saturation of hydrocarbons $\left(\mathrm{S}_{\mathrm{HC}}\right)$.

The value of $R w$ for this region has been calculated in different steps. The values of bottom hole temperature (B.H.T) $\left(152^{\circ} \mathrm{F}\right)$, surface temperature (S.T) $\left(80^{\circ} \mathrm{F}\right)$ has been taken from log header to calculate the Geothermal gradient (G.G) by the following equation (Zahid et al, 2014):

G. G $=\frac{\text { B. H. T }-S \cdot T}{\text { T. D }}$

Where, T.D = total depth $(7150$ feet $)$

The value of G.G (0.0100699) was then used to calculate the formation temperature (F.T) by using following equation (Zahid et al, 2014):

$\mathrm{F} . \mathrm{T}=($ Formation top $\times \mathrm{G} . \mathrm{G})+\mathrm{S} . \mathrm{T}$

Once the value of formation temperature is determined (147.46으), GEN charts were then used to determine the resistivity of mud filtrate at formation temperature (refer the used chart here). The resistivity of mud filtrate (Rmf) at surface temperature has been taken from log header and it was $1.9 \mathrm{ohm}-\mathrm{m}$, this value has been plotted on GEN chart to determine the resistivity of mud filtrate at formation temperature and it turned out to be $0.25 \mathrm{ohm}-\mathrm{m}$ (Figure 3).

At formation temperature Rmf is calculated, using GEN chart $\mathrm{Rmf}$ equivalent is then calculated by plotting $\mathrm{Rmf}$ at formation temperature on $\mathrm{x}$-axis and then extending it up till formation temperature and then extending it straight towards Rmf equivalent or $\mathrm{y}$-axis and it was $0.2 \mathrm{ohm}-\mathrm{m}$ (Figure 4).

$\mathrm{Rw}$ equivalent is calculated using GEN charts after calculating Rmf equivalent for which static spontaneous potential was find out by using SP log and it resulted to be $-35 \mathrm{mV}$ and was plotted on $\mathrm{x}$-axis, overextended up till temperature lines, from where line has been stretched horizontally till $\mathrm{Rmf}$ equivalent value and then finally $\mathrm{Rw}$ equivalent value was determined by stretching line till $R w$ equivalent line and it was $0.2 \mathrm{ohm}-\mathrm{m}$ (Figure 5).

The last step was to find the $R w$ value. The value was find out through GEN chart but this time Rw equivalent value was plotted on $y$-axis which was overextended till 


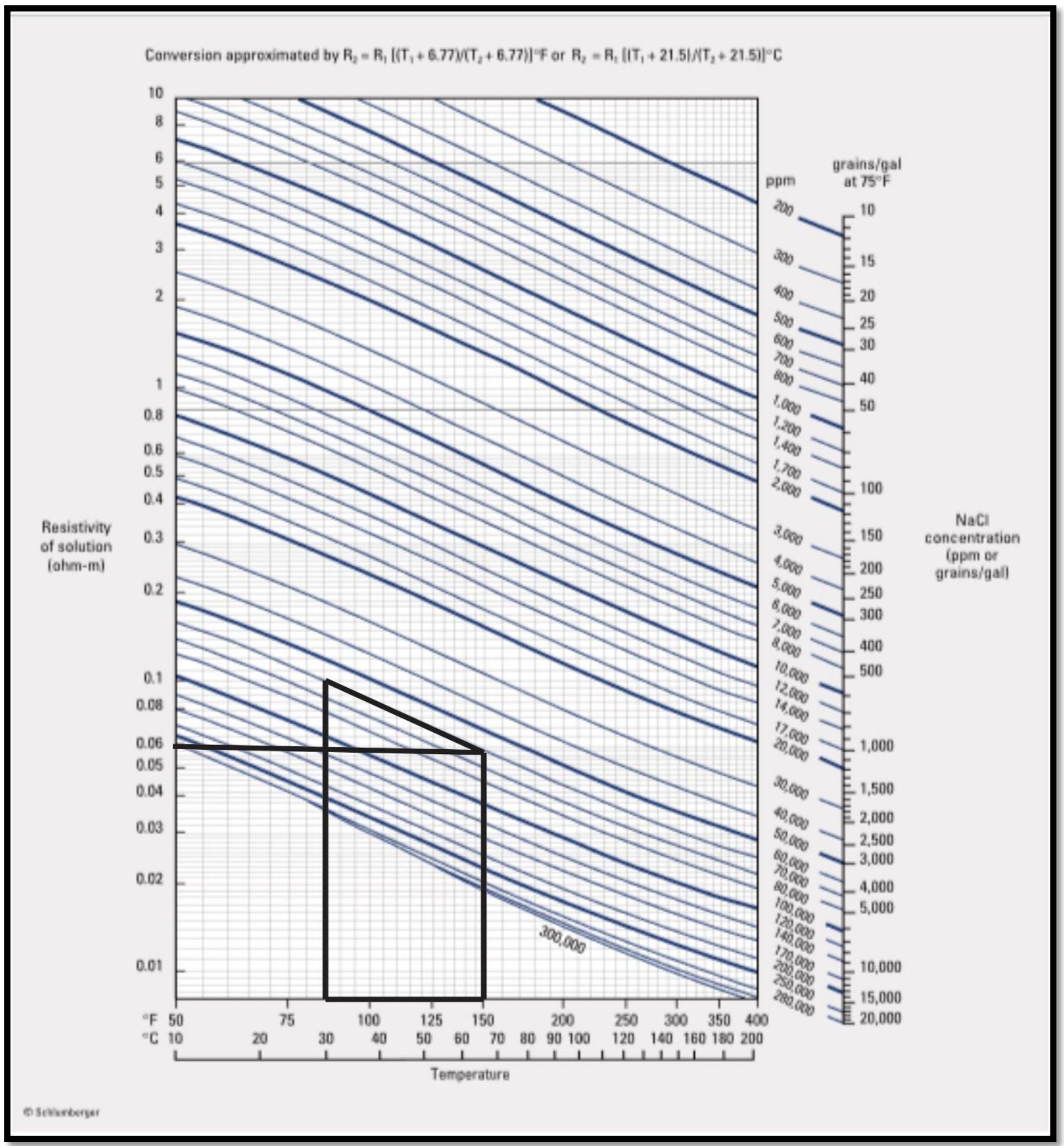

Figure 3. Showing calculation of Rmf at the formation temperature of Minwal X-01(Schlumberger, 1972).

temperature lines and was then stretched vertically downwards till $\mathrm{Rw}$ or $\mathrm{x}$-axis and the value of $\mathrm{Rw}$ for area of interest $(\mathrm{AOI}-1)$ has resulted to be $0.25 \mathrm{ohm}-\mathrm{m}$ (Figure
5).

After finding the value of resistivity of water, the saturation of water was calculated by using the formula 


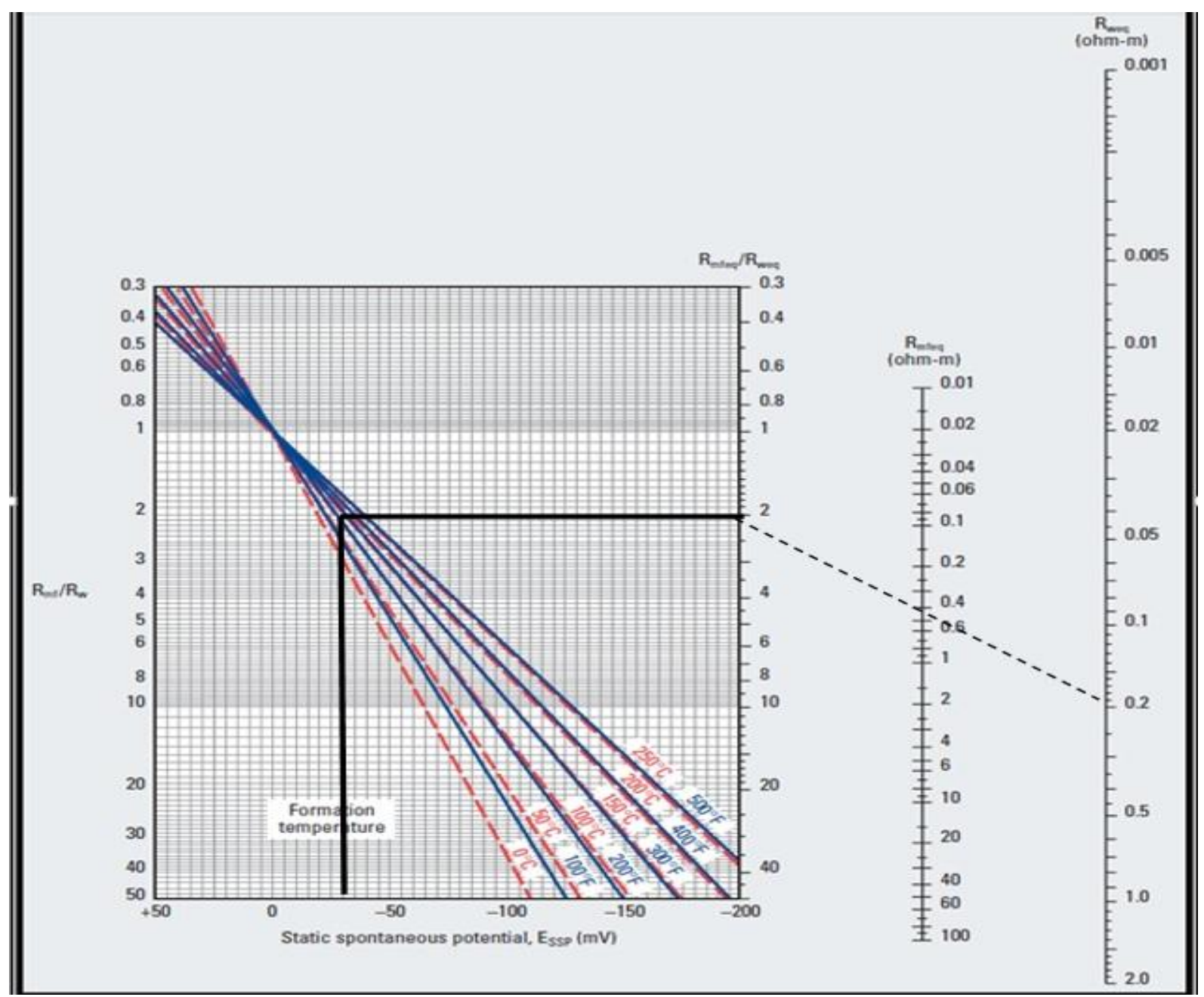

Figure 4. Showing calculation of Rw equivalent of Minwal X-01 (Schlumberger, 1972).

below.

$\mathrm{S}_{\mathrm{w}}=\sqrt{\left(\frac{\mathrm{a}}{\varphi^{\mathrm{m}}}\right) \times\left(\frac{\mathrm{R}_{\mathrm{w}}}{\mathrm{R}_{\mathrm{t}}}\right)}$

Where: $\mathrm{Sw}=$ Water saturation, $\mathrm{a}=$ Tortuosity Factor, $\mathrm{m}=$ Cementation exponent, $\mathrm{Rt}=$ Resistivity of Un-invaded zone, $\mathrm{Rw}=$ Resistivity of formation water and $\Phi=$ Porosity.

\section{RESULTS}

Three zones were selected in Minwal X-01, and these areas were considered as an area of interest (AOI). These AOI were studied and analyzed through different well logs and computational analysis was carried out through different formulas for petrophysical inquiries and these three areas of interest were termed as $\mathrm{AOI}-1, \mathrm{AOI}-2$, and AOI-3 respectively. Based on the values of low gamma-ray values, these areas are selected having possibly low GR values and have high resistivity values. Though neutron and density log were not available, sonic log has been used to determine the porosity and its values were also supporting other logs that helped to mark the zones of interest. The detail of these zones is given in Tables 2, 3, and 4.

\section{Comparison of reservoir zones $(\mathbf{R z})$ in AOl's}

The three area of interests that have been marked for identification of a reservoir zones on the basis of different petrophysical parameters. Once all the petrophysical parameters were determined, finally the cut-off is applied on the basis of volume of shale, effective porosity and saturation of water which is described above. The comparison of the overall average values in these zones shows that these zones have quite high value of hydrocarbon saturation which is above $90 \%$. All of the three zones excellently fulfil the criteria of a good reservoir 


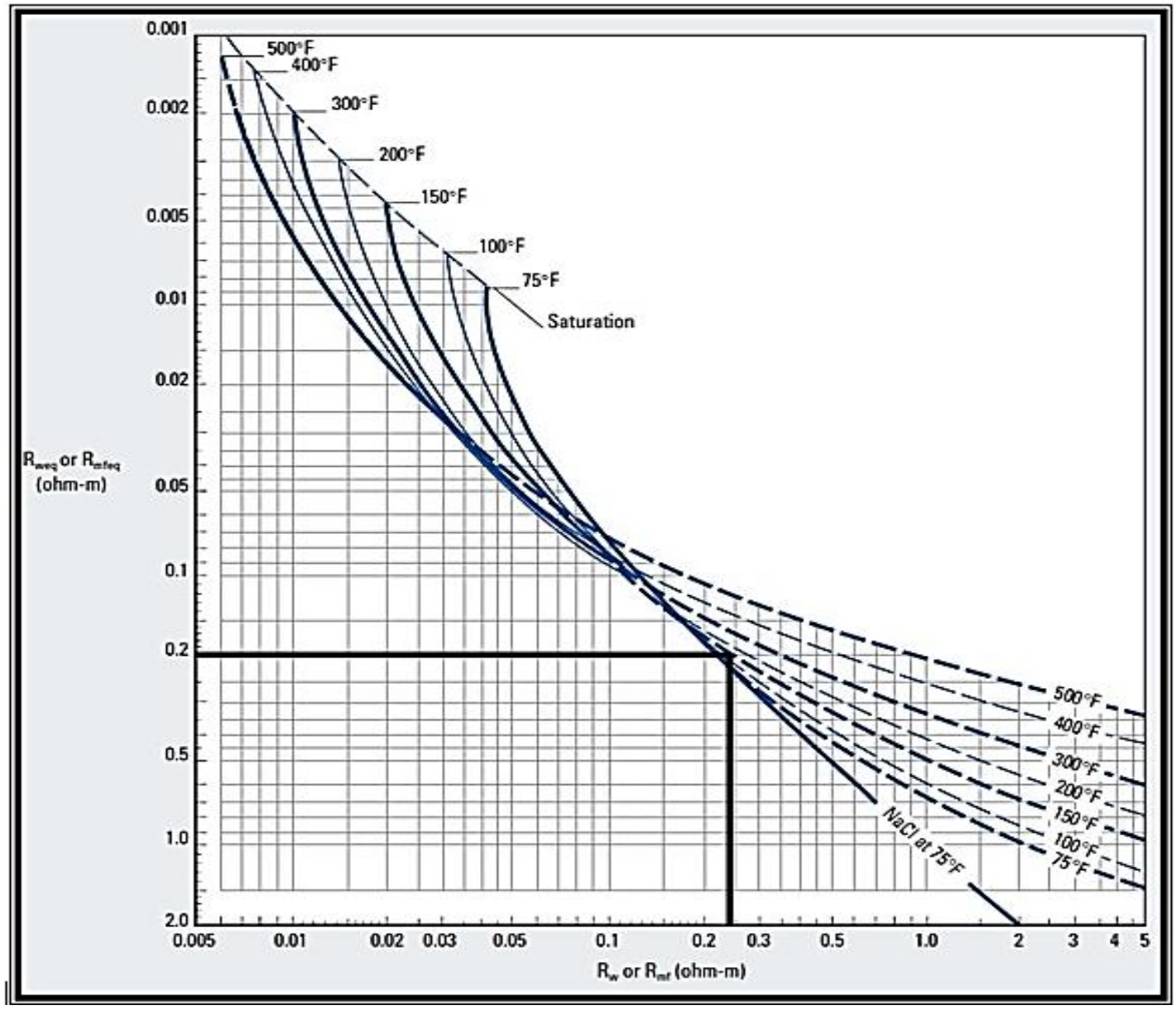

Figure 5. Showing calculation of Rw of Minwal X-01 (Schlumberger, 1972).

Table 2. Showing average values in reservoir zone within AOI-1.

\begin{tabular}{|c|c|c|c|c|c|c|}
\hline $\begin{array}{l}\text { Geological } \\
\text { Formation }\end{array}$ & Depth in Feet & $\begin{array}{c}\text { Shale Volume, } \\
\%\end{array}$ & $\begin{array}{c}\text { Effective } \\
\text { Sonic porosity } \\
\text { (Øs), \% }\end{array}$ & $\begin{array}{c}\text { Water } \\
\text { Saturation, \% }\end{array}$ & $\begin{array}{l}\text { Hydrocarbon } \\
\text { Saturation, \% }\end{array}$ & $\begin{array}{c}\text { Sonic } \\
\text { Porosity, \% }\end{array}$ \\
\hline \multirow{21}{*}{ Chorgali Formation } & 6744 & 15 & 21 & 7 & 93 & 25 \\
\hline & 6746 & 15 & 20 & 8 & 92 & 23 \\
\hline & 6748 & 15 & 21 & 7 & 93 & 24 \\
\hline & 6750 & 15 & 21 & 7 & 93 & 25 \\
\hline & 6752 & 15 & 23 & 7 & 93 & 27 \\
\hline & 6754 & 15 & 18 & 10 & 90 & 22 \\
\hline & 6756 & 25 & 12 & 13 & 87 & 16 \\
\hline & 6758 & 25 & 12 & 11 & 89 & 16 \\
\hline & 6760 & 25 & 12 & 9 & 91 & 16 \\
\hline & 6762 & 25 & 12 & 7 & 93 & 16 \\
\hline & 6764 & 25 & 12 & 7 & 93 & 16 \\
\hline & 6766 & 25 & 12 & 7 & 93 & 16 \\
\hline & 6768 & 25 & 12 & 7 & 93 & 16 \\
\hline & 6770 & 25 & 12 & 8 & 92 & 16 \\
\hline & 6772 & 25 & 12 & 9 & 91 & 16 \\
\hline & 6774 & 15 & 14 & 9 & 91 & 16 \\
\hline & 6776 & 15 & 14 & 9 & 91 & 16 \\
\hline & 6778 & 15 & 14 & 10 & 90 & 16 \\
\hline & 6780 & 15 & 16 & 8 & 92 & 19 \\
\hline & 6782 & 15 & 20 & 8 & 92 & 23 \\
\hline & Average & 19.5 & 15.5 & 8.4 & 91.6 & 19 \\
\hline Total Thickness & $\begin{array}{l}\text { Values, \% } \\
38\end{array}$ & & & & & \\
\hline
\end{tabular}


Table 3. Showing average values in reservoir zone within AOI-2.

\begin{tabular}{lcccccc}
\hline $\begin{array}{l}\text { Geological } \\
\text { Formation }\end{array}$ & Depth(feet) & $\begin{array}{c}\text { Shale } \\
\text { Volume, \% }\end{array}$ & $\begin{array}{c}\text { Effective Sonic } \\
\text { porosity (Øs), \% }\end{array}$ & $\begin{array}{c}\text { Water } \\
\text { Saturation, \% }\end{array}$ & $\begin{array}{c}\text { Hydrocarbon } \\
\text { Saturation, \% }\end{array}$ & $\begin{array}{c}\text { Sonic } \\
\text { Porosity, \% }\end{array}$ \\
\hline & 6926 & 17 & 13 & 3 & 97 & 16 \\
& 6928 & 17 & 13 & 3 & 97 & 16 \\
& 6932 & 17 & 13 & 3 & 97 & 16 \\
Chorgali & 6936 & 17 & 13 & 3 & 97 & 16 \\
Formation & 6940 & 17 & 13 & 3 & 97 & 16 \\
& 6942 & 17 & 13 & 3 & 97 & 16 \\
& 6944 & 17 & 13 & 3 & 97 & 23 \\
& 6946 & 17 & 13 & 3 & 98 & 16 \\
Total & 6948 & 17 & 19 & 2 & 98 & 17.4 \\
Thickness & 6950 & 17 & 19 & 2 & 97.2 & \\
\hline
\end{tabular}

Table 4. Showing average value/results in reservoir zone within AOI-3.

\begin{tabular}{lcccccc}
\hline $\begin{array}{l}\text { Geological } \\
\text { Formation }\end{array}$ & Depth (feet) & $\begin{array}{c}\text { Shale } \\
\text { Volume, \% }\end{array}$ & $\begin{array}{c}\text { Sonic } \\
\text { Porosity, \% }\end{array}$ & $\begin{array}{c}\text { Effective Sonic } \\
\text { porosity (Øs), \% }\end{array}$ & $\begin{array}{c}\text { Water } \\
\text { Saturation, } \\
\%\end{array}$ & $\begin{array}{c}\text { Hydrocarbon } \\
\text { Saturation, \% }\end{array}$ \\
\hline & 7000 & 29 & 12 & 9 & 5 & 95 \\
& 7002 & 29 & 12 & 9 & 10 & 90 \\
& 7004 & 29 & 12 & 9 & 5 & 95 \\
Sakesar & 7006 & 29 & 12 & 9 & 4 & 96 \\
Limestone & 7008 & 29 & 12 & 9 & 4 & 96 \\
& 7010 & 29 & 12 & 9 & 4 & 95 \\
& 7012 & 29 & 12 & 9 & 5 & 95 \\
& 7020 & 22 & 11 & 9 & 6 & 96 \\
& 7022 & 22 & 11 & 9 & 5 & 95 \\
Total Thickness & 7024 & 22 & 11 & 9 & 4 & 96 \\
& 7026 & 22 & 11 & 9 & 5 & 94.84 \\
\hline
\end{tabular}

zone as the volume of shale in all three zones is within the range of 17 to $25 \%$. The lowest value of Sw noted in $\mathrm{Rz}$ AOI-2 is $2.8 \%$ and highest value has been find out in $\mathrm{Rz}$ AOI-1 which is $8.41 \%$, where all these values are low supporting good reservoir zone. A good effective porosity always hold good amount of hydrocarbon, in all the three reservoir zones the values of the effective porosity falls within the range of 9 to $16.29 \%$ which is quite good range of porosity and all these values support the criteria of hydrocarbon rich zone. After considering these parameters and applying cut-off values the reservoir zone turned out to be 52 feet in AOI- 1 while it is 20,26 feet respectively in AOI-2 and AOI-3. These details are shown in Table 4.

On the basis of net pay thickness, $\mathrm{Rz}$ in AOI- 1 is determined as most prolific and productive zone of the three zones because it gives more net pay thickness. However, no area of interest or reservoir zone is marked except Sakesar Limestone and Chorgali Formation.

\section{DISCUSSION}

The Potwar Sub-basin belongs to the category of extra 

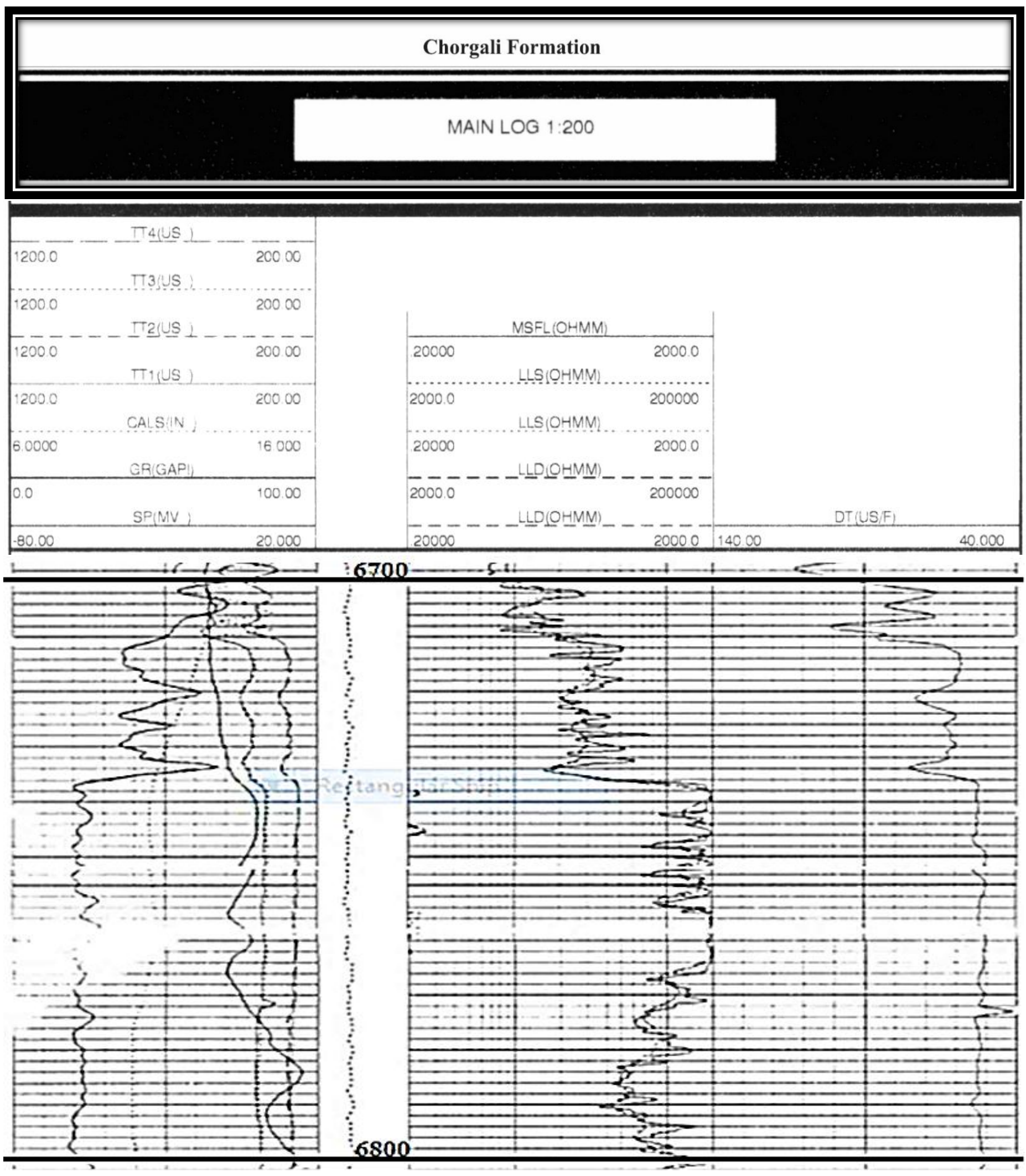

Figure 6. Showing Log trend of AOI-1.

continental down warp basins. This accounts for $48 \%$ of the world known petroleum (Riva 1983). The thick 
Chorgali Formation

MAIN LOG 1:200

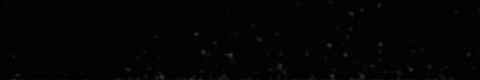

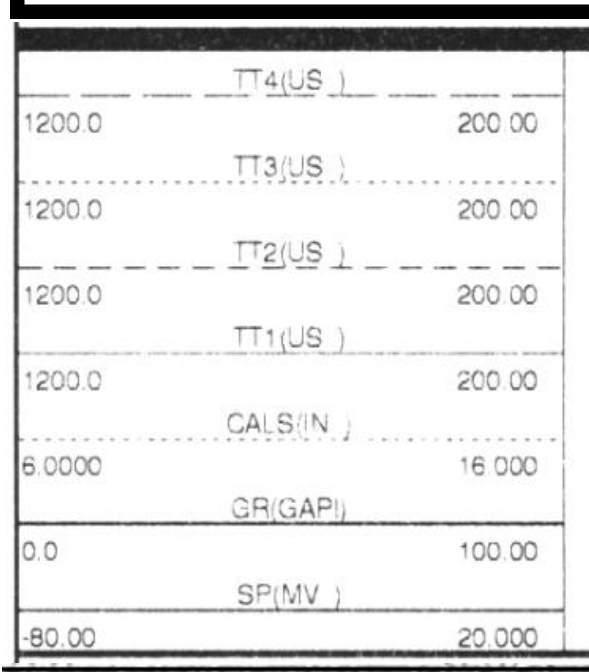

\begin{tabular}{|c|c|}
\hline \multicolumn{2}{|c|}{ MSFL (OHMM) } \\
\hline 20000 & 2000.0 \\
\hline 2000.0 & 200000 \\
\hline 20000 & 2000.0 \\
\hline \multicolumn{2}{|c|}{$\overline{2000.0}---10-10$} \\
\hline--- & --- \\
\hline 20000 & 20000 \\
\hline
\end{tabular}
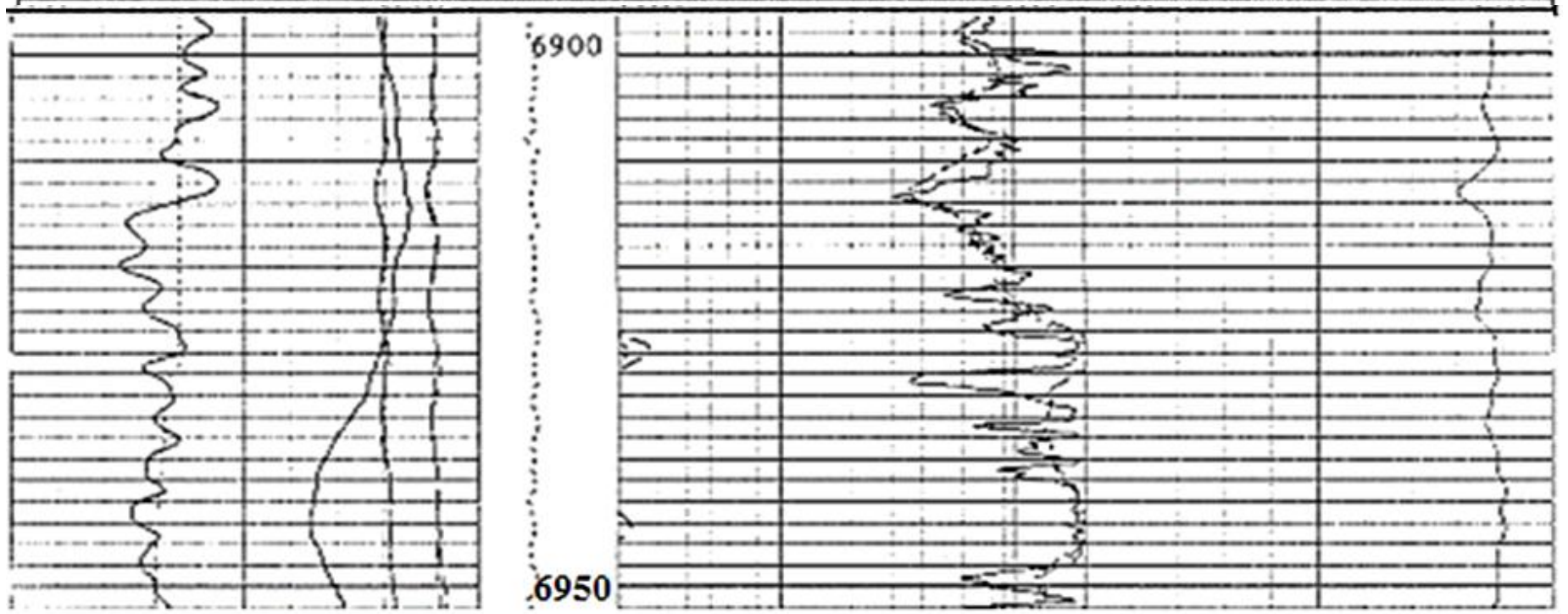

Figure 7. Showing Log trend of AOI-2.

overburden of 3047 meters $(\mathrm{m})$ of molasse provides burial depth and optimum geothermal gradient for oil formation (Shami and Baig 2002). In the current study, Minwal X-01 well was evaluated by using different petrophysical parameters in order to find out its hydrocarbon potential regardless of its productivity. In Minwal X-01 three area of interest were selected in order to evaluate different formations for hydrocarbon potential. The Chorgali/Sakesar limestone is the main producer from Joya Mair Oil Field (Shami and Baig 2002). Sakesar and
Chorgali formations in Minwal X-01 are acting as a favourable hydrocarbon potential reservoir hosting formations. Other formations were assessed but do not qualify the possessions of a reservoir zone. AOI-1 lies in Chorgali Formation below the Murree Formation and above Sakesar Limestone (Figure 6). AOI-2 also lies in the Chorgali Formation below the Murree Formation and above Sakesar Limestone (Figure 7). AOI-3 lies in Sakesar Limestone lies below the Chorgali Formation (Figure 8). The details of these investigations in Minwal X- 


\section{Sakesar Limstone}

MAIN LOG 1:200
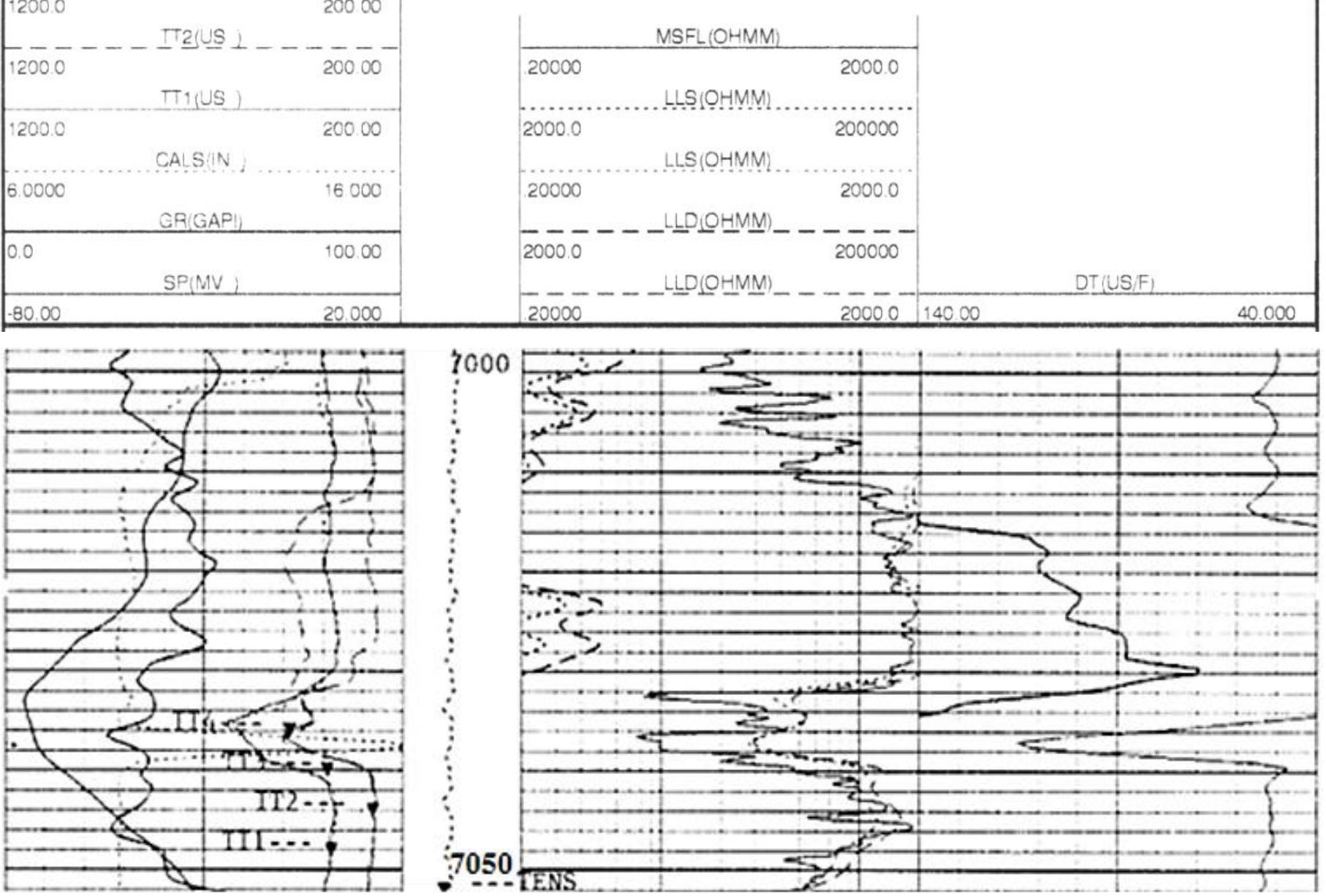

Figure 8. Showing Gamma-ray log trend of AOI-3.

01 are: (a) The average shale volume values in AOI-1 was found to be $18.75 \%$ and effective porosity $19.75 \%$. The fracture porosity is relatively higher in wells of northwestern Potwar because the rocks deformed several times during the Himalayan orogeny (Zahid et al 2014). Saturation of water was $8.41 \%$ and saturation of hydrocarbons $91.58 \%$. The reservoir rock is Sakesar Limestone that occurs at the depth of $\sim 2023 \mathrm{~m}$ interpreted from seismic data. From the petrophysical analysis it is clear that the Minwal X-01 well is hydrocarbon saturated well containing an average of about $78.75 \%$ oil in its pores spaces (Zahid et al 2014). Net pay thickness found in the reservoir rocks after applying cut-off in this study was 52 feet. (b) The average shale volume values in AOI-2 was found to be $17 \%$, effective porosity $17.4 \%$, saturation of water was $2.8 \%$, saturation of hydrocarbons was $97.2 \%$. Net pay thickness found after applying cut-off on AOI-2 was 20 feet. (c) The average shale volume values in AOI-3 
was found to be $25.76 \%$, effective porosity $11.53 \%$, saturation of water was $5.15 \%$ saturation of hydrocarbons $94.84 \%$. Net pay thickness found after applying cut-off on AOI-3 was 26 feet. The reservoir rocks show low primary porosity and contained low temperature viscous oil. These factors cause restriction in migration of oil and allows it to flow mainly along the open fractures (Zahid et al 2014).

\section{Conclusion}

Based on the calculated petrophysical parameters and analysis, it is established that in Minwal X-01 well, Sakesar and Chorgali formations is displaying fair to good hydrocarbon saturation, so these are reflected as likely to be economically probable reservoirs.

\section{REFERENCES}

Asquith, G. B., Krygowski, D. (2004). Basic Well Log Analysis: AAPG Methods in Exploration 16, P, 31-35.

Darling, T., (2005), Well logging and formation evaluation, Gulf Professional Publishing, USA. Pp 5-6.

Fatmi, A. N. (1973), Lithostratigraphic units of the Kohat-Potwar Province, Indus Basin, Pakistan. Ibid, Rec, 21(2), 9p.

Gansser, A. (1981). The geodynamic history of the Himalaya. Zagros Hindu Kush Himalaya Geodynamic Evolution, 3, 111-121.

Kadri, I. B. (1995). Petroleum Geology of Pakistan, Published by Pakistan Petroleum Limited, Ferozsons (pvt) limited.

Khan, M. A., Ahmed, R., Raza, H. A., and Kemal, A. (1986). Geology of petroleum in Kohat-Potwar Depression, Pakistan: American Association of Petroleum Geologists Bulletin, 70(4), 396-414.
Mehmood, W., Adil, N., Jadoon, Y. K. (2015). Evaluation of Petrophysical properties for reservoir characterization of Eocene age in Meyal field, Potwar basin - Pakistan: Sci.Int. (Lahore), 27(5).

Rider, M., H. (2002). The Geological Interpretation of Well Logs. Second Edition (Revised) Chapter 1, Pp. 7-8.

Rider, M. H. (1996). The Geological Interpretation of Well Logs, Second Edition, Gulf Publishing Company, Houston. 280p.

Riva, J. P.Jr. (1983). World petroleum resources and reserves. Boulder, Colorado, westview press. 355.

Searle, M. P., Cooper, D. J. W., Rex, A. J., \& Colchen, M. (1988). Collision tectonics of the Ladakh-Zanskar Himalaya. Phil. Trans. R. Soc. Lond. A, 326(1589), 117-150.

Schlumberger (1972). Schlumberger Log interpretation charts, Houston, TX.

Schlumberger, (1967). Well Evaluation Conference, Middle East

Selley, R. C. (2000). Applied Sedimentology, Academia press USA, p 58.

Shami, B., \& Baig, M. (2002). In Geomodeling for enhancement of hydrocarbon potential of Joya Mair Field (Potwar) Pakistan, PAPG-SPE Annual Technical Conference, Islamabad. Pp. 124-145.

Zahid, M., Khan, A., Rashid, U. M., Saboor, A., Ahmad, S. (2014), Structural interpretation of Joya Mair oil field, south Potwar, Upper Indus Basin, Pakistan, using ,2D seismic data and petrophysical analysis. Journal of Himalayan Earth Science, 47(1), 73-86. 